\title{
KETTŐS MEZŐORIENTÁCIÓS SZABÁLYOZÁSI STRUKTÚRA MECHANIKAI ÉRZÉKELŐ NÉLKÜLI KALICKÁS INDUKCIÓS MOTOROS HAJTÁS RÉSZÉRE
}

\section{DOUBLE FIELD-ORIENTED CONTROL STRUCTURE FOR SENSORLESS CAGE INDUCTION MOTOR DRIVE}

\author{
Imecs Mária \\ Kolozsvári Müszaki Egyetem, Villamosmérnöki Kar, Villamos Gépek és Hajtások \\ Tanszék, Románia, Kolozsvár, str. Bariţiu 28, maria.imecs@emd.utcluj.ro
}

\begin{abstract}
The paper presents two simple vector control structures without speed sensor for induction motor drives fed by a voltage-source inverter (VSI) with open-loop voltage-controlled space-phasor-based pulse-width modulation procedure, which are suitable for implementation with help of digital signal processors dedicated to controlled electrical drives. The speed feedback value is generated by a torque, respectively a torque-producing current-component-controller in cascade combination with the speed controller. In order to reduce the rotor-parameter dependence in the computation of the forward control variables, the double field-orientation is applied, and the calculus of the controlled rotor-flux feedback value is made by compensation with the leakage fluxes of the stator flux, which is identified from the measured phase currents and voltages. The stator-current control variables are directly generated by the speed and flux controllers as rotor-field-oriented components and the stator-voltage control variables are computed in stator-field-oriented coordinates. Consequently, there are combined the advantages of two types of field-orientation procedures avoiding the rotor-resistance dependency and conferring good control dynamics and stability, robust behavior at reduced computation capacity and motor-parameter-dependence.
\end{abstract}

Keywords: Space Vector Modulation (SVM), direct field-orientation, slip-frequency compensation, DC-link frequency converter, vector control, digital implementation, voltagesource inverter (VSI)

\section{Összefoglalás}

A dolgozatban bemutatott két egyszerü vektoriális szabályozási struktúra a nyílt hurkú térfázoros feszültség típusú ISzM-mel vezérelt feszültségforrás jellegü váltóirányítóról táplált mechanikai érzékelő nélküli kalickás indukciós motoros hajtásokra alkalmazható, melyek implementációra alkalmasak a hajtástechnikának szánt digitális jelfeldolgozó vezérlőegységekkel. A sebességvisszacsatolás jelét a sebességszabályozóval kaszkádban bekötött nyomaték-, illetve nyomatékképző aktív áramösszetevőszabályzó generálja. A rotorellenállás-függőség elkerülésére a vezérlőágban kettős mezőorientációt alkalmazunk, és a visszacsatolásokhoz szükséges rotorfluxust a mért fázisáramokból és feszültségekből identifikált sztátorfluxusból a szórási fluxusok kompenzálásával számoljuk. Ezek szerint az állórészáram alapjelének a generálása forgórészfluxus szerinti mezőorientált összetevőkkel, míg az állórészfeszültség vezérlő mennyiségeinek a számítása állórészfluxus szerinti mezőorientált koordinátákkal történik. Így lehet egyesíteni a két mezőorientációs eljárás előnyeit, kiküszöbölve a rotorellenállás-függőséget, ezáltal biztosítva a jó szabályozási dinamikát és stabilitást, robusztus viselkedést, alacsonyabb számítási kapacitás és alacsony motorparaméter-függőség mellett.

Kulcsszavak: térfázoros impulzusszélesség-moduláció, direkt/közvetett mezöorientáció, csúszás-kompenzálás, egyenáramú közbensőkörös frekvenciaváltó, vektoriális szabályozás, numerikus implementáció, feszültséginverter 


\section{Bevezető}

A kalickás (rövidrezárt forgórészü) indukciós motor (KIM) a kefe nélküli (angolul „Brushless”) forgómezős váltakozó áramú (VÁ) gépek kategóriájába tartozik. A hagyományos villamos gépek között a legegyszerübb, a legolcsóbb és a legrobusztusabb; kevés karbantartást igényel, és az üzemeltetése a legbiztonságosabbak közé tartozik. Ennek köszönhetően a legelterjedtebb gép a villamos hajtásokban.

A korszerü villamos hajtásokban $(\mathrm{VH})$ háromfázisú VÁ motorokat alkalmaznak, melyek matematikai modelljei (MaMo) változó paraméterüek, többváltozósak, bonyolult belső kapcsolatokkal. A nemlineáris MaMo-knak tulajdonítható, hogy ezeknek a VH-knak szabályozása bonyolult és sokáig nehezen kivitelezhetö volt. A modern $\mathrm{VH}-$ technikában a szabályozás elméleti hátterét a térfázor (TF - Park-vektor) elméleten alapuló (vektoriális vagy mátrixos) állapotváltozós, úgynevezett általános egyenletrendszerek szolgáltatják [1], [2].

A vektoriális szabályozási rendszerek a mezőorientáció (MO) elvén alapulnak, és szétcsatolt többváltozós struktúrákhoz vezetnek, melyek a TF-es MaMo-kat figyelembe véve, az egyenáramú (EÁ) motorokhoz hasonlóan a VÁ motorokat szabályozhatóvá teszik. Mindez nem történhetett volna meg a teljesítményelektronikának és a számítástechnikának az utóbbi évtizedek során bekövetkezett robbanásszerü fejlődése nélkül [3], [4], [5], [6 ].

A VÁ-VH szabályozására a beavatkozó szerv egy statikus frekvenciaváltó (SzFV), mellyel az úgynevezett ,veszteség nélküli” szabályozást lehet biztosítani. Az SzFV-k nagyrészt feszültségforrás jellegü (FFJ) egyenáramú közbensőkörös (EÁ-KK) felépítésűek, a hálózat felől egyszerübb esetben diódás egyenirányítóval (DEI) és a hajtómotor felé impulzusszélességmodulációval (ISzM) vezérelt IGBT-s
(,Isolated-Gate Bipolar Transistor”) FFJ váltóirányítóval (FVI, angolul VSI „Voltage-Source Inverter”), mellyel kvázi szinuszos VÁ-t lehet megvalósítani, ugyanakkor a kimeneti frekvencia és feszültség amplitudójának a változtatásával a VÁVH-t szabályozni lehet [7], [8], [9], [10].

A felépítésénél fogva FVI nem mindenképpen müködik FFJ-vel. A hajtómotor betáplálásának a feszültség- vagy áramforrás jellegét (ÁFJ) az FVI-nek alkalmazott ISzM-s vezérléseljárás határozza meg, ami lehet nyílt hurkú feszültségalapjellel vezérelt (ebben az esetben megőrződik a zFFJ) [8], vagy zárt hurkú áramalapjellel szabályozott, mely esetben az FVI ÁFJ-vel fog viselkedni a közvetlen áramvisszacsatolásnak tulajdoníthatóan. Ez utóbbi a VH dinamikája és stabilitása szempontjából sokkal elönyösebb [9], [10].

A VH-technikának szánt és a piaci forgalomban lévő digitális jelfeldolgozó vezérlőegységek (DJF-VE) a gyakorlati kivitelezésében viszont csak nyílt hurkú feszültségISzM eljárásokat tesznek lehetővé, kizárva az áram-visszacsatolásos ISzM-módszereket, melyekkel viszont a VH-kban jobb szabályozási minőséget lehet megvalósítani. A kettős mezőorientáció (KMO) az adott feltételek mellett megpróbálja a különböző rendszerek megoldásainak előnyeit egy struktúrában érvényesíteni [11], [12], [13].

Az utóbbi években a mechanikai érzékelők nélküli rendszerek újra az érdeklődés központjába kerültek. Előnyei közé sorolhatjuk a kisebb méretet, a csökkentett zajérzékenységet, a szenzorkábelek kiküszöbölését, az egyszerübb hardver igényt. Barátságtalan környezetben is többnyire mechanikai érzékelővel nem rendelkező motorokra van szükség. Az évek során a sebességérzékelő nélküli technikák széles skáláját fejlesztették ki. Ezek közé tartoznak a nyílt hurkú becslök, a referenciamodell alapú adaptív rendszerek (MRAS - "Model Reference Adaptive System"), a Luenberger megfigye- 
lők, a Kálmán-szürős eljárások stb. Mindezek ellenére a mechanikai érzékelő nélküli technikák legfőbb hátránya a leszükített sebességtartomány, amely korlátozza az ipari alkalmazhatóságát [14].

Nem túl igényes sebességszabályozást egyszerübb struktúrákkal is meg lehet oldani, melyeknek az egyik hátrányos oldala viszont a paraméterfüggőség [1], [15], [16] [17]. Ezeknek a gyakorlati implementációra való alkalmassága KMO alkalmazásával megoldható, és mellyel a rotorellenállásfüggősége $\left(R_{r}\right)$ elkerülhető. Az alábbiakban ezek a szabályozási rendszerek kerülnek bemutatásra.

\section{A forgómezős motorok kéthurkú vektoriális szabályozása}

A VÁ gépekben a forgómezőt az állórészben háromfázisú tekercseléssel valósítjuk meg. A külső gerjesztésü kompenzált EÁ motoroknál a mechanikai és mágneses mennyiségek szabályozása a sajátos felépítésüknek köszönhetően, két egymástól független hurokban valósítható meg, az armatúra, illetve a gerjesztő tekercsek segítségével. A VÁ motornál ez a természetes szétcsatolás közvetlenül nem vehető észre, sem a háromfázisú felépítésükből (KIM-nél gerjesztés sincs), sem a MaMo-ból, a matematikai nemlinearitások miatt. Ezért a VÁ motorok elektromágneses szempontból sokkal nehezebben tanulmányozhatók, és szabályozásuk is jóval bonyolultabb.

\subsection{A háromfázisú motorok kéthurkú szabályozása}

Ha a VÁ motoroknál csak az állórészben avatkozhatunk be, akkor szabályozásra csak két referencia-alapjelt lehet elöírni, ugyanis az SzFV-vel a betápláló sztátorfeszültségnek ugyancsak két paraméterét (frekvencia- és alapharmonikus amplitúdó) lehet változtatni. Következésképpen az EÁ motorokhoz hasonlóan két külső főhurkos szabályozási struktúrát lehet kialakítani.
Ezek az KIM-nél a mechanikai mennyiségekre (pozíció, sebesség, nyomaték, aktív áram), illetve a mágneses mennyiségekre (eredő fluxusok, mágnesezési áramok) vonatkozhatnak. Egy adott terhelönyomaték hatása alatt a villamos motor akkor üzemel optimálisan, azaz akkor szívja a minimális áramot, ha függetlenül a sebességtől a fluxus amplitúdóját a névleges értéken tartjuk. Ezt a KIM-nél a tápfeszültség amplitúdójának és frekvenciájának a beállításával érhetjük el. Mivel a betáplálási frekvenciát a meghajtott munkagép üzemi körülményei (a terhelőnyomaték és elöírt fordulatszám) szabják meg, a fluxus állandó értéken tartása a feszültség amplitúdójának a megfelelő megválasztásával történik skaláris (lehet akár nyílt hurkú is) vagy zárt hurkú vektoriális szabályozása által.

A kéthurkú szétcsatolt szabályozást vektoriálisan, az MO elve alapján lehet megvalósítani. Ebben az esetben szükség van nemcsak a fluxus értékének (modulusának), hanem helyzetszögének (pozíciójának) is az identifikációjára [1], [5], [18], [19], [20].

\subsection{Vektoriális szabályozás a mező- orientáció elve alapján}

Az MO a villamos gépek nyomatékon alapuló analógiájához vezet. A nyomatékképzést a MaMo-ban egy vektoriális szorzat írja le, melynek Ampère törvénye alapján az egyik komponense mindenképpen a mágneses mező, a másik pedig egy olyan áram, melynek iránya a mező mágnesezési tengelyének az irányától eltér. A KIM-nél az elektromágneses nyomatékot (EMNy) fel lehet írni bármelyik eredő $\left(\underline{\Psi}_{s}-\right.$ állórész/sztátor-, $\underline{\boldsymbol{\Psi}}_{r}$ - forgórész-/rotor- vagy $\underline{\boldsymbol{\Psi}}_{m}-$ légrés-/ mágnesezési, azaz a hasznos) fluxussal és a megfelelő árammal:

$$
\begin{aligned}
& \boldsymbol{m}_{e}=k_{M I} z_{p}\left(\underline{\boldsymbol{i}}_{r} \boldsymbol{x} \underline{\boldsymbol{\Psi}}_{r}\right)=k_{M I} z_{p}\left(\underline{\boldsymbol{i}}_{r} \boldsymbol{x} \underline{\boldsymbol{\Psi}}_{m}\right)=k_{M I} z_{p} \\
& \left(\underline{\boldsymbol{\Psi}}_{m} \boldsymbol{x} \underline{\boldsymbol{i}}_{s}\right)=k_{M 1} z_{p}\left(\underline{\boldsymbol{\Psi}}_{s} \boldsymbol{x} \underline{\boldsymbol{i}}_{s}\right),
\end{aligned}
$$

ahol a $z_{p}$ a póluspárok száma, $k_{M I}=3 / 2$ az egy póluspárra eső nyomatékkoefficiens, mely a térfázor meghatározási koefficiensé- 
től függ (ebben az esetben $k_{P h}=2 / 3$ ) [1], [2], [3].

Az MO-t tehát elvileg három fluxus szerint végezhetjük el. Ezek csak a szórási fluxusokban $\left(\underline{\boldsymbol{\Psi}}_{\sigma s}\right.$ és $\left.\underline{\boldsymbol{\Psi}}_{\sigma r}\right)$ különböznek, melyek nemcsak a fluxusvektorok nagyságát, hanem a térbeli pozíciójukat is befolyásolják, mint ahogyan az 1. ábrán is látható.

A koordinátarendszer (KooR) MO-ja azt jelenti, hogy a komplex sík d (,direct”) valós tengelyét ráforgatjuk a megfelelö szögelfordulással $\left(\lambda_{s}\right.$, vagy $\left.\lambda_{r}\right)$ valamelyik forgó fluxusnak megfelelö TF-re (q a „quadrature" imaginárius tengely). Akkor az orientációs fluxusösszetevők a saját MOs KooR-jükben [1], [2], [12]:

$\Psi_{r d \lambda r}=\Psi_{r}=\left|\underline{\Psi}_{r}\right|=\underline{\boldsymbol{\Psi}}_{r}$ és $\Psi_{r q \lambda r}=0$, illetve $\Psi_{s d \lambda s}=\Psi_{s}=\left|\underline{\Psi}_{s}\right|=\underline{\Psi}_{s}$ és $\Psi_{s q \lambda s}=0$.

$\mathrm{Az}$ állórész-orientált fix tengelyhez képest az összes TF átlagosan a szinkron sebességgel forog, ezért a mezőorientált öszszetevők (vetületek) EÁ jellegű változók állandósult üzemmódban állandó mennyiségek, melyek az egyenáramú jelleget a tranziens folyamatok alkalmával is megőrzik. Ezek szerint mezőorientációval a KIMt a szabályozási struktúrában, mesterségesen, egy ekvivalens EÁ géppé alakítjuk át [1], [21]. Így, az eredeti VÁ motort EÁ-ban szétcsatolva szabályozzuk, majd a vezérlő mennyiségeket visszaalakítjuk természetes szinuszos (állórész-orientált KooR-re vonatkoztatott) mennyiségekre, azaz a KooR-t visszaforgatjuk. Ennek következtében a két szétcsatolt szabályozási hurkot vektoriálisan összecsatoljuk, megörizve a beavatkozó változók vektoriális jellegét [1], [5], [18], [20].

Visszaforgatáskor a beavatkozó jel (áram vagy feszültség TF) térbeli pozíciójának a meghatározására a vektoriális rendszer kötelezően megköveteli visszacsatolásként az orientációs $\left(\underline{\boldsymbol{\Psi}}_{S}\right.$ vagy $\left.\underline{\Psi}_{r}\right)$ mezőnek megfelelö TF $\lambda_{s}$, illetve $\lambda_{r}$ szögelfordu- lását, melynek az időbeli változása (deriváltja) adja a forgó fluxus szögsebességét:

$\omega_{\lambda s}=\mathrm{d} \lambda_{s} / \mathrm{d} t$ és $\omega_{\lambda r}=\mathrm{d} \lambda_{r} / \mathrm{d} t$,

melyek állandósult állapotban vagy állandó fluxus- és áramviszonyok mellett egyenlők:

$\omega_{\lambda s}=\omega_{\lambda r}=z_{p} \Omega_{0}=2 \pi f_{s}$,

ahol $\Omega_{0}$ a szinkron szögsebesség (mechanikai szögben mérve), mely meghatározza a hajtás üzemeltetési $f_{s}$ frekvenciáját és az $\underline{\boldsymbol{e}}_{\lambda s}=\mathrm{j} \omega_{\lambda s} \underline{\boldsymbol{\Psi}}_{s}$ indukált forgási elektromotoros feszültséget (EMF), mely látható az 1. ábrán.

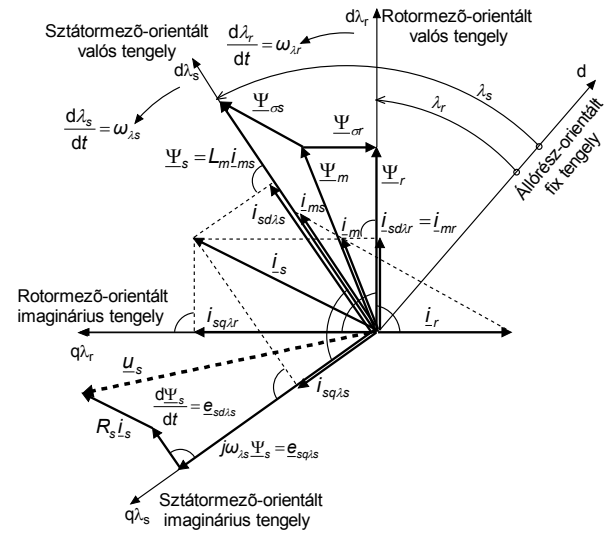

1. ábra. A kalickás indukciós motor térfázordiagramja szabályozott forgórészfluxus $\left(\Psi_{r}=c t\right.$.) esetén, a sztátor áram mezöorientált összetevöivel: a nyomatékképzők $i_{s q \lambda r} \perp \underline{\Psi}_{r}$ és $i_{s q \lambda_{s}} \perp \underline{\Psi}_{s}$, valamint a reaktiv jellegüek $i_{s d \lambda r}=i_{m r}$ és $i_{s d \lambda s} \neq i_{m s}$.

Ezek szerint az előírt frekvencia értékére vonatkozó információt a vezérlő mennyiség TF pozíciószöge rejtett módon (belsőleg) tartalmazza, és a KIM kapcsain természetszerüen magától adódik. Ez azzal magyarázható, hogy a vektoriális szabályozásnak köszönhetően a vezérlésre szolgáló áram vagy feszültség TF-je jó dinamikával követi az orientációs mező forgását, ugyanis a $\lambda$ szögvisszacsatolás az úgynevezett önkommutációt/szabályozást biztosít (angolul 
„Self-commutation/control”), mely a szinkron típusú gépek vezérlésére jellemző.

A vektoriális szabályozási rendszerekben mind a beavatkozó jel generálása, mind a beavatkozó SzFV vezérlése is vektoriális jelleggel kell hogy rendelkezzék. Vezérlésre vagy poláris koordinátákkal dolgozunk, ami azt jelenti, hogy a modulus mellett a vektorok (TF-ek) fázisszögét is azonosítani kell, vagy olyan háromfázisú koordinátákkal, amik megőrzik a vektoriális jelleget, áramban vagy feszültségben, attól függően, hogy milyen típusú a SzFV kimenetén az inverter és annak az ISzM vezérlése.

\subsection{Az orientációs mező megválasz- tása}

A rotorfluxus $\underline{\Psi}_{r}$ szerinti mezőorientáció (RMO) klasszikusnak tekinthető a KIMes VH-k szabályozásában. Mivel a forgórész tekercseinek megfelelő rudak felépítésüknél fogva rövidre vannak zárva, tehát $u_{r}$ $=0$, és emellett, ha a $\Psi_{r}$ fluxus amplitúdója állandónak tekinthető (állandósult állapotban vagy/és szabályozott fluxussal müködő VH esetében), akkor az $\underline{i}_{r}$ rotoráram és a $\underline{\Psi}_{r}$ rotorfluxus TF-jei merőlegesek egymásra (lásd az 1. ábrát). Ennek a merőlegességnek köszönhetöen a KIM EMNy-je ennek a két mennyiségnek nemcsak a vektoriális szorzatával, hanem azok modulusának a szorzataként is kifejezhetö. Ugyancsak az $\underline{i}_{r}$ $\perp \underline{\Psi}_{r}$ sajátosságnak a következménye, hogy a sztátoráram TF-jének a két vetülete, $i_{s d \lambda r}$ (a fluxussal egyirányú $\mathrm{d}$ - direkt, reaktív jellegü) és $i_{s q \lambda r}$ (a fluxusra merőleges q kvadratúra, aktív jellegü) mezőorientált áram-összetevőknek felelnek meg, melyek arányosak a nyomatékképző változókkal:

$m_{e}=-k_{M} \Psi_{r} i_{r}=k_{M r} L_{m} i_{m r} i_{s q \lambda r}=$

$k_{M r} L_{m} i_{s d \lambda r} i_{s q \lambda r}$

ahol $i_{m r}=\Psi_{\mathrm{r}} / L_{m}$ a rotorfluxussal arányos mágnesezési áram, $L_{m}$ a háromfázisú hasznos induktivitás és $\sigma_{r}=L_{\sigma r} / L_{m}$ a rotor szórási koefficiense. Tehát a mezőorientált sztátor-áram: $\underline{\boldsymbol{i}}_{s}=i_{s d \lambda r}+\mathrm{j} i_{s q \lambda r}$, ahol az RMO-s összetevők

$i_{s d \lambda r}=i_{m r}=\Psi_{r} / L_{m}$ és $i_{s q \lambda r}=-\left(1+\sigma_{r}\right) i_{r}$. 6)

Az (1) és (5) szerint az EMNy képlete az $\underline{i}_{s}$ RMO-s $\left(i_{s q \lambda r}\right)$ és hasonlóképpen az SMO-s $\left(i_{s q \lambda s}\right)$ aktív áramösszetevővel is felírható:

$m_{e}==k_{M r} \Psi_{r} i_{s q \lambda r}=k_{M} \Psi_{s} i_{s q \lambda s}$,

ahol $K_{M r}=k_{M l} z_{p} /\left(1+\sigma_{r}\right)=k_{M} /\left(1+\sigma_{r}\right)$.

$\mathrm{Az}$ MO-s KooR-ben a fluxusra meröleges áramösszetevő minden esetben aktív, azaz nyomatékképző, viszont a fluxussal egyirányú összetevő csak a RMO-s KIMnál arányos a szabályozott fluxussal [1], [2], [12]. A fentiek szerint az RMO esetén a mezőorientált áramösszetevők közvetlenül generálhatók a fluxus, illetve a sebesség vagy a nyomaték szabályozókkal. Ezenkívül az állandó rotorfluxusnak megfelelő statikus mechanikai jelleggörbék a sebességnyomaték síknegyedekben párhuzamos egyenesekhez vezetnek, melyek hasonlóak a külső gerjesztésű EÁ gépek jelleggörbéivel. Ez azt jelenti, hogy a KIM-nak megnő a statikus stabilitása, túlterhelési kapacitása is nagyobb lesz, ugyanakkor gyorsabban reagál a szabályozás alkalmával, azaz jobb a vezérelhetőségi dinamikája [3], [11].

A sztátorfluxus szerinti mezőorientáció (SMO) esetén a fluxusszabályozóból generált $i_{m s}$ mágnesezési áram nem egyenlő a $\mathrm{d}$ irányú $i_{s d \lambda s}$ összetevővel (lásd az 1. ábrát). A különbség terhelés-, azaz csúszásfüggő [2]. Ezenkívül a sztátorfluxus szabályozása gyengébb minőségü rendszerre vezet stabilitás és dinamika szempontjából is, ezért a szétcsatolt szabályozásra kevésbé javasolt [11], [12]. Viszont ha az SzFV FFJ nyílthurkú ISzM-es eljárással vezérelt, a sztátorfeszültség vezérlőjelének a számolása SMO KooR-ben sokkal egyszerübb, és ami lényegesebb, nem rotorparaméter-függő [1], [12].

\subsection{A kettős mezőorientáció alkalma- zása}

A KMO ötletét a KIM vektoriális struktúráinak implementációja során adódott 
kompromisszumos megoldások hátrányainak az elkerülésére való törekvés váltotta ki.

Az RMO-val szabályozott, ÁFJ-vel müködő SzFV-ről táplált KIM hajtásnak van a legegyszerübb és a motorparaméterektől legkevésbé függő vektoriális szabályozási struktúrája, mely csökkentett számítási kapacitást igényel, és az EÁM-hoz hasonló viselkedéssel (kiváló dinamika, a legjobb statikus stabilitás és túlterhelhetőség) üzemel. A beavatkozó vezérlési jelszámítás teljesen motorparaméter független. Sajnos a használatos DJF-VE-k nem támogatják a fent említett rendszerek megvalósításához szükséges zárt hurkú ÁFJ ISzM eljárás implementálását, ugyanis csak a nyílt hurkú feszültségben vezérelt (vivőhullámos vagy TF-es) ISzM módszerekett teszik lehetővé.

Az RMO-val szabályozott, FFJ-vel müködő SzFV-ről táplált KIM hajtás, annak ellenére, hogy jó statikus stabilitással és jó dinamikus viselkedéssel rendelkezik, a szabályozási struktúrája bonyolult, és magas a számítási szükséglete, valamint a nagy rotorparaméter-függősége miatt jobb minőségü, nem túl költséges VH-khoz nem ajánlott. Ezek a hátrányok SMO-val elkerülhetők, viszont ezzel a VH stabilitása és viselkedése más szempontok miatt romlik le.

SMO-val szabályozott, FFJ-vel müködő SzFV-ről táplált KIM hajtás szabályozási struktúrája egyszerü, kevésbé számításigényes, kvázi paraméterfüggetlen számításokat igényel. Robusztus viselkedése ellenére lustábban reagál a sebességalapjel változására és a nyomatékperturbációra. Kis tehetetlenségü VH-k esetén stabilitási problémák léphetnek fel.

Az előzőek alapján egy olyan struktúra, mely egyesíti az említett rendszerek előnyeit és implementálási lehetőségeit KMO-val valósítható meg, melynek az alkalmazásával jelentősen meg lehet javítani a feszültségben vezérelt KIM-os VH minőségét, ugyanis ezáltal nagyrészt kiküszöbölhetőek a két eljárás hátrányai, a következőképpen: a rotorfluxus-szabályozás megnöveli a stabilitást az sztátárfluxus-szabályozással szemben; a sztátor-áram RMO-s összetevőit a fluxus és a sebesség szabályozók közvetlenül generálják, ezáltal leegyszerüsödik a struktúra alapjelképző része, és megnövekedik a VH dinamikája; az SMO az állórész-feszültség vezérlő mennyiségeinek a számítását leegyszerüsíti és rotorparaméterfüggetlenné teszi, megnöveli a $\mathrm{VH}$ robosztus viselkedését.

A KIM KMO-s struktúráját és a szimulálási eredményeit először 2008-ban hoztuk nyilvánosságra angol nyelvü közleményekben [22], [23], [24], majd 2009-ben magyarul is [13]. Az implementációs eredmények közlésére 2011-ben került sor [25], [26], [27].

\section{Sebességérzékelő nélküli mező- orientációs indukciós motoros hajtások}

A csúszáskompenzálást (CsKo) a skaláris szabályozásokban is alkalmazták az SzFV vezérlési frekvenciájának a meghatározására, ahol a csúszást a sebességszabályozó generálhatja [5], [18], [20]. Olcsóbb, kisebb számítási kapacitást igénylö, viszont elfogadható pontosságú gyakorlati kivitelezésre alkalmas, mechanikai érzékelő nélküli sebességszabályozásnak megfelelnek egyszerübb megoldások is, melyek a csúszáskompenzálás eljárást alkalmazzák a sebesség vagy a frekvencia meghatározásához [1], [10], [21], [22].

\subsection{Csúszáskompenzálás direkt és indirekt rotormező-orientációs struktúrákban}

$\mathrm{Az}$ indirekt (közvetett) mezőorientáció (IMO) a CsKo eljáráson alapul. A csúszás abszolút értékéből és a forgórész megmért $\omega_{r}$ szögsebességböl (mechanikai szögben mérve) meg lehet határozni azt a szögsebességet

$$
\omega_{\lambda r}=\Delta \omega+z_{p} \omega_{r},
$$


mely megfelel a (4) alapján a szinkronsebességnek és megadja a betáplálási frekvenciát.

A csúszás számítása RMO-s struktúrákban nem okoz gondot, ugyanis a sztátoráram RMO-s összetevőinek az arányával számolható ki, akár az alapjelekből [5], [18], [20], akár a visszacsatolásból származó jelekkel kombinálva, akár a visszacsatolásban az I- $\Omega$-nak nevezett rotorfluxus identifikációs eljárásból (a sztátoráram és a forgórész szögsebességéböl a rotor-feszültség MaMo alapján) származó értékekből [1], [12]:

$$
\Delta \omega=i_{s q \lambda r} / i_{s d \lambda r} \tau_{r},
$$

ahol $\tau_{r}=L_{r} / R_{r},=L_{m}\left(1+\sigma_{r}\right) / R_{r}$, a rotor időállandója ( $L_{r}-$ a rotor 3-fázisú induktivitása).

Ha a vezérlési ágban a (8) és a (9) alapján számított szinkronsebességből integrálás útján nyert $\lambda_{r}$ mezőorientációs szöggel forgatunk vissza [1], [16], [17], akkor IMOról beszélünk [11], [15].

Direkt (közvetlen) mezőorientáció (DMO) esetén a $\lambda$ mezőorientációs szöget a forgó orientációs fluxus állórész-orientált (szinuszos) kétfázisú összetevőiből egy VA segítségével közvetlenül számoljuk ki [1], [2], [11]. Ha a fluxusidentifikáció az $\underline{\boldsymbol{e}}_{s}$ sztátor EMF integrálásával történik (a sztátorfeszültség MaMo alapján), akkor a (7)-et a mechanikai érzékelő nélküli rendszerekben a forgórészsebesség meghatározására is lehet használni:

$$
\omega=z_{p} \omega_{r}=\omega_{\lambda r}-\Delta \omega,
$$

ahol $\omega$ villamos szögben következik. Ilyen sebességérzékelő nélküli DMO-s vektoriális VH-t is javasoltunk az [1]-ben.

Japánban már a '80-as évek végén ipari alkalmazást nyert egy egyszerü, nem túl igényes, de elfogadhatóan pontos sebességszabályozás, mely aktív (nyomatékképző) áramösszetevővisszacsatoláson alapszik, és CsKo-val alkalmaz IMO-t [15]. Hasonló struktúrájú az a rendszer is, melyet az [1]ben mutattunk be és szimulálási eredményeit a [16] és [17]-ben közöltük. Ezekben a struktúrákban a csúszásszámításban a (9)ban szereplő reaktív jellegü áramösszetevőt, a (6) alapján, a szabályozott fluxus alapjelével helyettesítették.

A CsKo hátránya abban áll, hogy a csúszás számításához szükség van a rotorparaméterekre, éspedig az $R_{r}$-re, melynek az értéke a hőmérsékletváltozás miatt széles határok között mozog, és melynek az identifikációja bonyolult és nagy számítási kapacitást igényel.

\subsection{Kaszkádkapcsolású szabályozóval generált sebességvisszacsatolás}

Az előzőekben említett mechanikai érzékelő nélküli hajtások egyszerü szabályozási struktúrái $R_{r}$-függőek, mert mindegyik valamilyen formában alkalmazza a CsKo-t [1], [15], [16], [17]. Ezenkívül a beavatkozó szerv közvetlen áramvisszacsatolással szabályozott SzFV, ami nem kompatibilis a VH-technikai alkalmazásoknak szánt DJFVE-kkel. Áttérve a feszültségben való vezérlésre RMO-val a rotorparaméterfüggőség még hangsúlyozottabb lesz. Azokban az áram ISzM-mel vezérelt FVI-s mechanikai érzékelö nélküli KIM VH-kban, melyek a [15]-ben alkalmazott megoldáshoz hasonlóak, ahol kaszkádban kapcsolt aktív áramszabályozóval generálják a sebesség visszacsatolási értékét (vagy helyette akár nyomatékszabályozót is lehet alkalmazni), mindnél ki lehet küszöbölni a CsKo alkalmazását, és meg lehet szüntetni a $R_{r}$ függőséget, ha olyan DMO-t alkalmazunk, melynél az orientációs mezőt az EMF integrálása alapján számoljuk.

Az implementációra alkalmas feszültség ISz-M-mel vezérelt FVI-s VH-k esetében viszont a sztátorfeszültség számítását csak a KMO-val lehet $R_{r}$-függetlenné tenni. Az alábbiakban két ilyen szabályozási rendszer kerül bemutatásra. 


\section{Kettős mezőorientációs sebes- ségérzékelő nélküli szabályozá- si struktúrák}

Az elözőkben már láthattuk, hogy ha a mechanikai érzékelö nélküli hajtásokban a sebességvisszacsatolásban nem alkalmazunk CsKo-t, és az orientációs fluxus identifikálása az sztátorfeszültség egyenletei alapján történik a mért sztátoráramok és feszültségek segítségével, akkor az $R_{r}$ függőség megszüntethetö. Ezt a fluxusidentifikációs módszert régebben csak a teljes hullámmal müködő inverterekről táplált VÁ motoroknál használták, főleg az ÁFJ váltóirányítós (CSI - „,Current-Source Inverter") VH-knál, ahol a feszültséget is meg tudták mérni, ugyanis ezeknél a feszültséghullám eléggé megközelíti a szinuszos formát [1]. Viszont nem lehetett alkalmazni FFJ ISzM-FVI inverterről táplált hajtások esetében, mert annak idején a szaggatott feszültséget nem tudták valós időben azonosítani, ugyanis az ISzM vezérlés analóg módon történt. Napjainkban egyébként a digitális ISzM vezérlésnek köszönhetően ez a módszer terjedt el a leginkább. Az szaggatott sztátor-feszültséget gyakran a mért EE-KK feszültségből $\left(U_{d}\right)$ és a DJF-VE által szolgáltatott ISzM logikából számolják ki [13], [22], [23], [24].

Ennek a fluxusidentifikációnak a gyakorlati megvalósításával járó nehézségek implementációban ma már megoldhatók. Például az ideális integrátort alul-áteresztő szürőkkel meg lehet közelíteni, amivel elkerülhető az integrátor kimenőjelének a zérusfrekvenciájú mérési maradékfeszültségek által okozott telítődése, valamint a kimenőjel eltolódása, amit a bemenőjel kezdeti fázishelyzete okozhat [11], [28], [29].

Az alábbiakban két olyan KMO-s struktúráról lesz szó, melyeket a [13], [22], [23] és [24]-ben közölt mechanikai érzékelős változat adaptálásával alakítottuk ki, alkalmazva az aktív hurokban egy kaszkádban bekötött visszacsatolási sebességértéket generáló szabályozót. Mindegyik szabályozási rendszer direkt (közvetlen) RMO-ra és SMO-ra épül.

\subsection{Aktív áramszabályozóval generált sebességvisszacsatolás}

A 2. ábrán bemutatott struktúrában a sebesség szabályozásához szükséges viszszacsatolási sebességértéket az SMO-s aktív (nyomatékképző) áramösszetevő kaszkádba kapcsolt szabályozójával generáljuk. A struktúra többi része megegyezik azzal a már szimulálás által érvényesnek elfogadott változattal, ahol viszont a sebesség visszacsatolását mechanikai érzékelö adta [13], [22], [23], [24.

A fluxus meghatározása a mért állórészáramok $\left(i_{s a, b, c}\right)$ és az identifikált $\left(u_{s}^{i d} a, b, c\right)$ feszültségekböl történik, miután a 3/2-es direkt fázistranszformációs blokkokkal kétfázisú összetevőkre $\left(i_{s d}-i_{s q}\right.$, illetve $\left.u_{s d}-u_{s q}\right)$ alakítjuk. Azután a természetes fix (állórészorientált) KooR-ben felírt sztátorfeszültség-egyenletek alapján az e e Id (Id identifikációs) blokkban az indukált EMF-t kétfázisú összetevőit $\left(e_{s d}-e_{s q}\right)$ számítjuk ki, melyeket a $\Psi_{\mathbf{s}} \mathbf{I d}$ blokkban integrálunk, és az állórészfluxus $\left(\Psi_{s d}-\Psi_{s q}\right)$ összetevőit nyerjük. Ezekből a $\boldsymbol{\Psi}_{\mathbf{s}} \boldsymbol{\Psi}_{\mathbf{r}} \mathbf{C o}$ kompenzáló blokkban, a mért sztátoráramok és a szórási koefficiensek segítségével, az áramfluxusegyenletek alapján, a rotorfluxus $\left(\Psi_{r d}-\Psi_{r q}\right)$ összetevőit számoljuk ki [1], [11], [16].

A kiszámított fluxusok $\Psi_{r}$ és $\Psi_{s}$ modulusát egy-egy VA vektoranalizátor adja. Mivel a vektoriális rendszerben különböző orientációjú kétfázisú összetevőkkel számolunk, ezért a TF-ek KooR-jeinek a forgatásához CooT blokkokat alkalmazunk, melyekben gyakorlatilag a TF-ek pozíciószögeinek a trigonometriai függvényeire van szükség. Ezeket $[\vartheta(\lambda)]=\left[\cos (\lambda, \sin \lambda]^{t}\right.$ úgynevezett „oszcillátor” mátrixokkal jelöltük, ahol zárójelben a orientációs TF pozíciója szerepel, illetve a szükséges forgatási szög. KMO esetén mindkét (rotor- és sztátor-) fluxus pozíciószögére szükség van. Mivel a 
fluxusszámításokat természetes kétfázisú összetevőkkel végezzük, azaz VÁ jelként kerülnek feldolgozásra, ezért a VA blokkokból közvetlenül az $\left[\vartheta\left(\lambda_{r}\right)\right]$ és $\left[\vartheta\left(\lambda_{s}\right)\right]$ mát- rixokkal jelölt változókat egyszerü osztásokkal $\left(\cos \lambda_{r / s}=\Psi_{r d / s d} / \Psi_{r / s}\right.$, illetve $\sin \lambda_{r / s}=$ $\left.\Psi_{r q / s q} / \Psi_{r / s}\right)$ számolhatjuk ki [1].

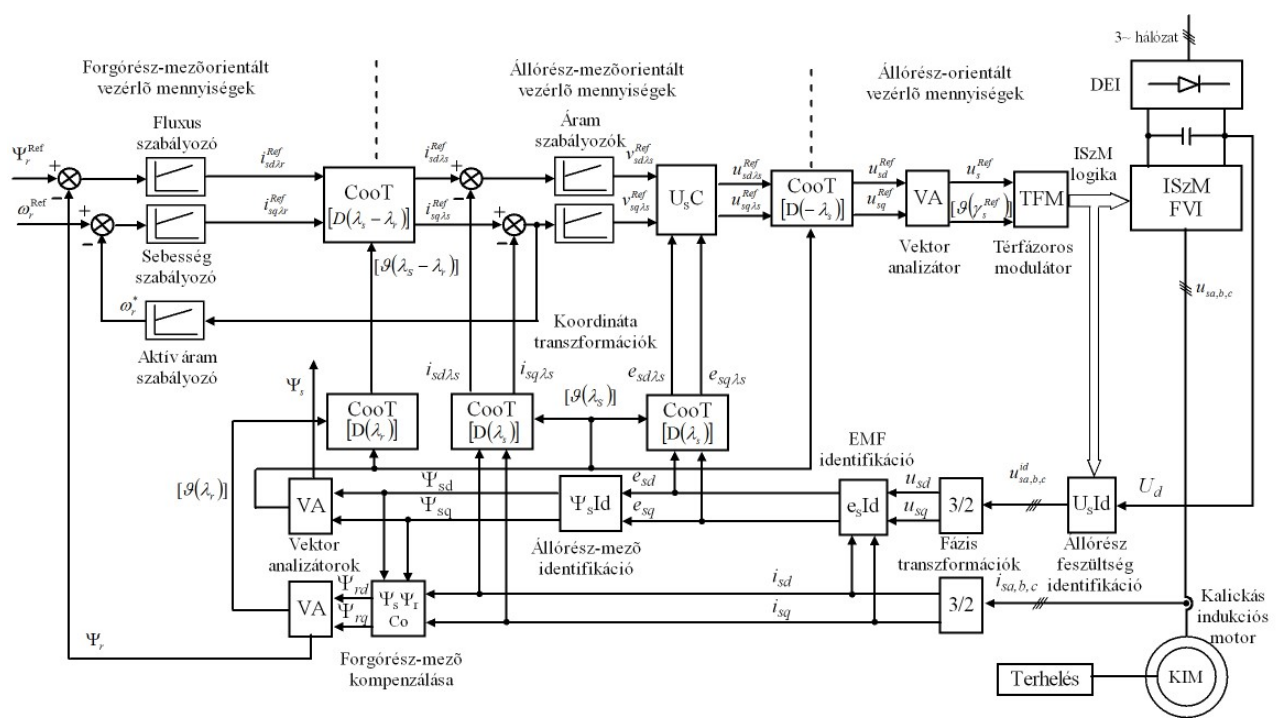

2. ábra. Implementációra alkalmas mechanikai érzékelö nélküli, egyszerübb struktúrájú kettős mezöorientációs vektoriális indukciós motoros hajtás nyomatékképzö aktív áramszabályozóval generált sebességvisszacsatolással.

Ugyancsak VA blokkot alkalmazunk a ISzM-FVI TF-es modulátornak (TFM blokk, angolul SVM - ,Space-Vector Modulator") a vezérlő jeleinek a generálására, mely a sztátorfeszültség alapjelének megfelelő TF poláris koordinátáinak, va-

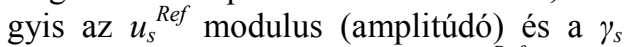
pozícióhelyzetnek megfelelő $\left[\vartheta\left(\gamma_{s}^{\text {Ref }}\right)\right]$ mátrix.

Az alárendelt áramszabályozási hurkokban az sztátoráram SMO-ját a $\left[\mathrm{D}\left(\lambda_{s}\right)\right]$ mátrixoperátorral jelölt, és az állórészfeszültség visszaorientálását természetes frekvenciájú kétfázisú összetevőire a [D($\left.\lambda_{s}\right)$ ]-vel jelölt CooT blokkal végezzük el. Az orientációs állórész-mező $\lambda_{\mathrm{s}}$ szögelfordulása az 1. ábra térfázor diagramján is látható.

Ezenkívül ugyancsak egy $\left[\mathrm{D}\left(\lambda_{r}\right)\right]$-vel jelölt CooT blokkal (melynek a kétfázisú komponens bemeneten a $\left[\vartheta\left(\lambda_{s}\right)\right]$ mátrixra van szükség) számolhatjuk ki a két orientációs mező közötti pozíciószög-különbség

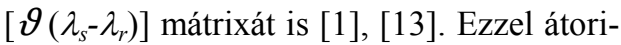
entálja SMO-s komponensekre $\left(i_{s d \lambda s}-i_{s q \lambda s}\right)$ a sebesség- és fluxusszabályozók által generált RMO-s állórészáram összetevőket $\left(i_{s d \lambda r}\right.$ - $i_{\text {sqגr }}$ ), ugyanis az SMO-s KooR-ben az állórészfeszültség számítását sokkal egyszerübben, és ami lényegesebb, rotorparaméter-függetlenül lehet elvégezni [1], [12]. Az állórészfeszültség $\mathbf{U}_{\mathbf{s}} \mathbf{C}$ számítási blokkjában szükség van az EMF SMO$\mathrm{s}\left(e_{s d \lambda s}\right.$, és $\left.e_{s q \lambda s}\right)$ komponenseire is, ezért a természetes ( $e_{s d}$ és $e_{s q}$ ) kétfázisú összetevőket is egy $\left[\mathrm{D}\left(\lambda_{s}\right)\right]$ mátrixszal jelölt CooT blokkal mezőorientáljuk.

A 2. ábrán bemutatott rendszerhez képest egy egyszerübb struktúrát úgy képezhetünk ki, hogy lemondunk a vezérlő ágban 
lévő két áramszabályozóról. Ebben az esetben a kaszkádkapcsolásban bekötött sebességet generáló áramszabályozó RMO-s aktív (nyomatékképző) összetevővel dolgozik, hasonlóképpen az [1], [15], [16] és [17]-ben közölt változatokhoz. Következésképpen a visszacsatolásban az állórész-áram természetes kétfázisú $\left(i_{s d}-i_{s q}\right)$ összetevőit $\left[\mathrm{D}\left(\lambda_{r}\right)\right]$ mátrixszal jelölt CooT blokkal kell mezőorientálni, és mivel csak az aktív $\left(i_{s q \lambda r}\right)$ komponensre van szükség, csak a mátrix felső sorával kell számolni, ami csak két szorzást jelent és egy összeadást a négy szorzás és két összegzés helyett.

\subsection{Nyomatékszabályozóval generált sebességvisszacsatolás}

Mint már említettük a 3 . fejezet végén, hogy a kaszkádban kapcsolt aktív áramszabályozó helyett lehet nyomatékszabályozóval is generálni a sebesség visszacsatolási jelét. Egy ilyen szabályozási struktúrát mutatunk be a 3. ábrán.

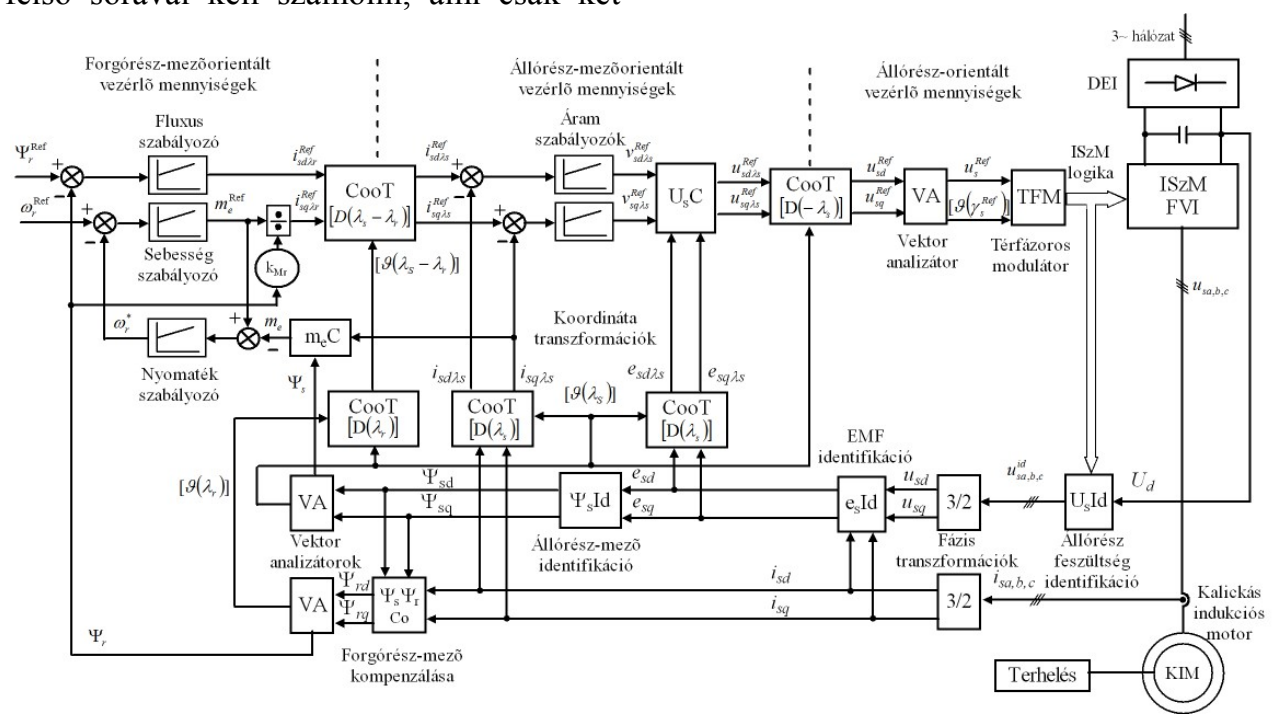

3. ábra. Implementációra alkalmas mechanikaiérzékelö nélküli kettös mezöorientációs vektoriális indukciós motoros hajtás kaszkádban kapcsolt nyomatékszabályozóval generált sebességvisszacsatolással.

Az $\quad \mathbf{m}_{\mathrm{e}} \mathbf{C}$ nyomatékszámítási blokk SMO-s, míg a nyomaték alapjelét osztó blokk RMO-s összetevőkkel számol a (7) szerint EÁ mennyiségekkel. Az osztásra fel lehet használni a rotorfluxus elöírt alapjelét is.

\section{Következtetések}

A bemutatott mechanikai érzékelő nélküli vektoriális szabályozási struktúrák egyszerüségét a kaszkádkapcsolású szabályzónak tulajdonítható, mely a nyomaték, illetve a nyomatékképző aktív áramösszetevő sza- bályozásával generálja a sebességvisszacsatolási értéket. Az implementáció szempontjából a piaci forgalomban lévő és a hajtástechnikának szánt digitális jelfeldolgozó vezérlőegységekkel való kompatibilitást a térfázoros feszültség ISzM eljárás biztosítja, mely a kommutációs veszteségek szempontjából optimizálható az úgynevezett kétfázisú (a harmadik fázis pihen) „Flat-Top" szakaszos modulációval, melylyel akár 30\%-os veszteségcsökkentést is el lehet érni az inverterben, vagy ennek hálózatbarát egyenirányítóként vagy aktív szü- 
rőként való alkalmazásánál [9], [10], [30], [31], [32]

A fluxusra merőleges áramösszetevő minden esetben aktív, azaz nyomatékképző komponens, viszont a fluxussal egyirányú összetevő a kalickás indukciós motornál csak abban az esetben arányos a szabályozott fluxussal, ha a forgórészfluxus szerint orientálunk Ezért ajánlott a rotormezöorientáció a szabályozási struktúra vezérlő ágában. A térfázoros ISzM viszont a paraméterfüggőség szempontjából sztátormezőorientációval előnyösebb. A kettős mezőorientációval mindkét orientációs eljárás előnye érvényesíthető, ha megfelelő fluxusidentifikációt alkalmazunk. A további kutatási munka célja a bemutatott rendszernek a tanulmányozása MATLAB-Simulink ${ }^{\circledR}$ szimulációs programozási környezetben.

\section{Szakirodalmi hivatkozások}

[1] Kelemen, Á., Imecs, M.: Vector Control of $A C$ Drives, Vol. 1: Vector Control of Induction Machine Drives. OMIKK-Publisher, Budapest, 1991. ISBN 9635931409.

[2] Imecs, M.: A villamos gépek modern szabályozási módszerei a térfázor elmélet alapján. Plenáris előadás, XVI. Fiatal Mủszakiak Tudományos Ülésszaka, FMTÜ Nemzetközi Tudományos Konferencia, Müszaki Tudományos Füzetek, Erdélyi Múzeum Egyesület kiadványa, Kolozsvár, 2011, ISSN 2067-6-808, http://eda.eme.ro/handle/10598/13994, XIX-XLIV.

[3] Imecs, M.: Villamos hajtások szabályozása mai szemmel. Plenáris előadás, ENELKO 2000, Energetika-Elektrotechnika Konferencia, EMT kiadó, Kolozsvár, 2000. 7-16.

[4] Imecs, M., Szabó Cs., Incze J. J.: Frekvenciaváltós villamos hajtások négynegyedes üzemmódban. ENELKO 2002 III. Energetika-Elektrotechnika Konferencia, EMT kiadó, Kolozsvár, 2002. 53-58.

[5] Imecs, M., Incze J. J., Szabó Cs., Ádám T.: Váltakozó áramú hajtások skaláris és vektoriális szabályozási struktúrái. Plenáris előadás, ENELKO 2003 IV. Energetika-Elektrotechnika Konferencia, EMT kiadó, Kolozsvár, 2003, ISBN 973-86097-5-5, 82-98.
[6] Imecs, M., Incze J. J., Szabó Cs., Ádám T., Szőke Benk Enikő: Kis és nagy teljesitményü hálózatbarát egyenáramú közbensö-körös frekvenciaváltós hajtások. Plenáris elöadás, ENELKO 2004., V. Nemzetközi EnergetikaElektrotechnika Konferencia, EMT kiadó, Kolozsvár, 2004, ISBN 973-86852-9-X, 86-96.

[7] Imecs, M.: Synthesis about pulse modulation methods in electrical drives, Part 1: Fundamental aspects. Plenáris elöadás, Proceedings of CNAE '98, Uni. Craiova kiadó, Romania, 1998, 19-28.

[8] Imecs, M.: Synthesis about pulse modulation methods in electrical drives, Part 2: Closed-loop current controlled PWM procedures. Plenáris előadás, Proceedings of CNAE '98, Uni. Craiova kiadó, Romania, 1998. 29-33.

[9] Imecs, M.: Synthesis about pulse modulation methods in electrical drives, Part 3: Open-loop voltage-controlled PWM procedures". Plenáris előadás, Acta Universitatis CIBIENSIS, Vol. XLI Technical series, H. Electrical Engineering and Electronics, "Lucian Blaga" University of Sibiu, 1999,15-26.

[10] Imecs, M., Open-loop voltage-controlled $P W M$ procedures. Proceedings of the $3^{\text {rd }}$ ELECTROMOTION International Conference, Patras, Greece, Volume I, 1999, 285-290.

[11] Imecs, M., Incze J. J., Szabó Cs.: Fluxusidentifikációs és szabályozási módszerek kalickás indukciós motorok mezőorientált hajtásrendszereiben. ENELKO 2009 X. Nemzetközi Energetika-Elektrotechnika Konferencia, Marosvásárhely, 2009, ISSN 1842-4546, 60-65.

[12] Imecs, M.: Kalickás indukciós motorok forgóés állórész mezöorientált vektoriális szabályozási rendszereinek összehasonlitása. ENELKO 2009 X. Nemzetközi EnergetikaElektrotechnika Konferencia, Marosvásárhely, 2009, ISSN 1842-4546, 66-71.

[13] Imecs, M., Szabó Cs., Incze J. J.: Kalickás indukciós motorok vektoriális szabályozása kettős mezö-orientációval. ENELKO 2009 X. Nemzetközi Energetika-Elektrotechnika Konferencia, Marosvásárhely 2009, ISSN 1842-4546, 72-77.

[14] Holtz J.: Sensorless control of induction motors, Proceedings of the IEEE, Vol.90, No.8, Aug. 2002, 1358-1394.

[15] Akeshi Maeda; Tung Hai Chin; Hiroichirou, Tanaka; Takashi, Koga; Ysugutosi, Ohtani: Today's AC drive industrial application in Japan. $4^{\text {th }}$ European Conference on Power Electronics 
and Applications, EPE'91, Florence, Italy, 1991, 2-618-2-624.

[16] Imecs, M., Negrea C. Alin, Szabó Cs., Incze J. J.: Sebességérzékelö nélküli aktív áramszabályozáson és közvetett mezöorientáción alapuló vektoriális aszinkron motoros hajtás szimulációja. ENELKO 2013 XIV. Nemzetközi Energetika-Elektrotechnika Konferencia, Nagyszeben, 2013, ISSN 1842-4546, 54-59.

[17] Negrea C. A., Imecs, M., Szabó Cs., Incze I. I.: Speed sensorless vector control system for induction motors based on active current and flux computation. Proceedings of the 4th International Conference MACRo 2013, Tg. Mures, Sapientia University, 2013, ISSN 2247 - 0948, ISSN-L 2247 - 0948, 154-163.

[18] Imecs, M., Szabó Cs.: Control structures of induction motor drives - state of the art. Proceedings of the 4th Workshop WESIC 2003, Lillafüred, Miskolci Egyetem kiadó, 2003, ISBN 963661 570, 495-510.

[19] Imecs, M., Trzynadlowski, A. M., Incze, I. I., Szabó Cs.: Vector control schemes for tandemconverter fed induction motor drives. IEEE Transactions on Power Electronics, 2005, Vol. 20, No. 2, 493-501.

[20] Imecs, M.: A survey of the speed and flux control structure of squirrel-cage induction motor drives. Acta Universitatis Sapientiae, Series Electrical and Mechanical Engineering, No. 1, 2009, ISSN 2066-8910 (online http://www.acta.sapientia.ro/acta-emeng/emengmain.htm), ISSN 2065-5916 (nyomtatásban) 5-28.

[21] Blaschke, F.: Das Prinzip der Feldorientierung, die Grundlage für die TransvektorRegelung von Drehfeldmaschinen. SiemensZeitschrift, 45, Heft 10, 1971, 757-760.

[22] Imecs, M.; Szabó Cs.; Incze I. I.: Vector control of the cage induction motor with dual field orientation. CINTI 2008, Budapest, 2008, ISBN 978-963-7154-82-9,. 47-58.

[23] Imecs, M., Incze, I. I., Szabó, Cs.: Double field orientated vector control structure for cage induction motor drive. Scientific Bulletin of the „Politehnica” University of Timisoara, Transaction of Power Engineering, Tom 53(67), Special Issue, 2008, ISSN 1582-7194, 135-140.

[24] Imecs, M., Incze, I. I., Szabó Cs.: Dual field orientation for vector controlled cage induction motors. Proc. of the $11^{\text {th }}$ IEEE International Conference on Intelligent Engineering Systems, INES 2009, Barbados, CD-ROM, ISBN: 978-14244-4111-2, 143-148.
[25] N. S. Preda, Maria Imecs, I. I. Incze: Vector control method for squirrel-cage induction motors using dual field orientation. PRODOC Conference Volume, Uni. Tehnica Cluj-Napoca, kiadó, Kolozsvár, 2011, CD-ROM.

[26] Preda, N. S., Rus, D. C., Imecs, M., Incze, J. J., Szabó, Cs.: Vector control method using dual field orientation for speed control of induction motors. ENELKO 2011 XII. Nemzetközi Energetika-Elektrotechnika Konferencia, Kolozsvár, 2011, ISSN 1842-4546, 68-74.

[27] Preda N. Şt.: Optimizarea şi implementarea controlului vectorial cu orientare dublă după câmp al maşinii asincrone cu rotor în colivie. $\mathrm{PhD}$ doktori tézis, Kolozsvári Műszaki Egyetem, 2011, Témavezető: Imecs Mária.

[28] Incze, I.I.: Implementarea unor structuri de comandă scalară şi reglare vectorială pentru motoare de inducţie. $\mathrm{PhD}$ tézis, KME, 2004, Témavezető: Imecs M.

[29] Incze I. I.; Imecs, Mária; Szabó, Cs.; Vásárhelyi J.: Orientation-field identifi-cation in asynchronous motor drive systems. $6^{\text {th }}$ IEEE International Carpathian Control Conference ICCC 2005, Lillafüred-Miskolc, 2005, Vol I, ISBN 963661644 2, 131-136.

[30] Preda, N. S., Incze, I. I., Imecs, M., Szabó, Cs.: Flat-top space-vector modulation implemented on a fixed-point DSP. $5^{\text {th }}$ International Symposium on Applied Computational Intelligence and Informatics, SACI 2009, Temesvár, CD-ROM, ISBN: 978-1-4244-44786.

[31] Preda, N. S., Rus, D. C., Incze, I. I., Imecs, M., Szabó, Cs.: Analysis and DSP implementation of flat-top space-vector modulation. Scientific Bulletin of "Politehnica" University of Timişoara, Romania, Transactions on Automation Control and Computer Science (BS-UPT TACCS), Vol. 55 (69), No. 2, June 2010, 73-80.

[32] Preda, N. S., Rus, D. C., Incze, I. I., Imecs, M., Szabó, Cs.: Fixed-point DSP implementation of advanced discontinuous PWM methods. $11^{\text {th }}$ International Carpathian Control Conference ICCC 2010, Eger, Miskolci Egyetem, 2010, ISBN 978-963-06-9289-2, 149-152. 